\title{
Morphological studies in a model for dengue-2 virus infection in mice
}

\author{
Ortrud Monika Barth/+, Débora Ferreira Barreto, Marciano Viana Paes*, \\ Christina Maeda Takiya**, Angela Teixeira Pinhão, Hermann Gonçalves Schatzmayr
}

\begin{abstract}
Departamento de Virologia *Departamento de Bioquímica e Biologia Molecular, Instituto Oswaldo Cruz-Fiocruz, Av. Brasil 4365, 21045-900 Rio de Janeiro, RJ, Brasil **Departamento de Histologia e Embriologia, Instituto de Ciências Biomédicas,

Universidade Federal do Rio de Janeiro, Rio de Janeiro, RJ, Brasil
\end{abstract}

\begin{abstract}
One of the main difficulties in studying dengue virus infection in humans and in developing a vaccine is the absence of a suitable animal model which develops the full spectrum of dengue fever, dengue haemorrhagic fever, and dengue shock syndrome. It is our proposal to present morphological aspects of an animal model which shows many similarities with the dengue infection in humans. BALB/c mice were intraperitoneally infected with non-neuroadapted dengue virus serotype 2 (DENV-2). Histopathological and morphometrical analyses of liver tissue revealed focal alterations along the infection, reaching wide-ranging portal and centrolobular veins congestion and sinusoidal cell death. Additional ultrastructural observations demonstrated multifocal endothelial injury, platelet recruitment, and alterated hepatocytes. Dengue virus antigen was detected in hepatocytes and in the capillar endothelium of the central lobular vein area. Liver function tests showed high levels of aspartate transaminase and alanine transaminase enzyme activity. Lung tissue showed interstitial pneumonia and mononuclear cells, interseptal oedema, hyperplasia, and hypertrophy of the bronchiolar epithelial cells. DENV-2 led to a transient inflammatory process, but caused focal alterations of the blood-exchange barrier. Viremia was observed from 2 nd to 11 th day p.i. by isolation of DENV-2 in C6/36 mosquito cell line inoculated with the supernatant of macerated liver, lung, kidney, and cerebellum tissues of the infected mice.
\end{abstract}

Key words: dengue-2 virus - BALB/c mice - liver - viremia - ultrastructure - histopathology

Dengue viruses (DENV) are mosquito-borne RNAviruses that are classified serologically into four antigenically distinct types (DENV-1, 2, 3, 4). They infect millions of people in tropical and subtropical regions of the world and may cause a mild to debilitating febrile illness, the classical dengue fever (DF), the dengue haemorrhagic fever (DHF), and dengue shock syndrome (DSS). However, the pathogenesis of human dengue infection (DEN) remains not sufficiently known, and no successful vaccine is available as yet (Eckels 1993). The studies on pathogenesis, pharmacodynamics, and prophylaxis of DHF have been hampered due to the lack of a suitable animal model (Bhamarapravati 1993).

DENV have been inoculated into numerous species of animals by a variety of routes. Studies on laboratory mice and non-human primates remain the most wellcharacterized models (Cole \& Wisseman 1969, 1973, Marchette et al. 1973, Boonpucknavig et al. 1981, Hotta et al. 1981a,b, Chaturvedi et al. 1991, Wu et al. 1995).

Several studies indicated that mice are a permissive host for DENV (Meiklejhon et al. 1952, Lin et al. 1998, Johnson \& Roehrig 1999, An et al. 1999). However, no infectious model that mimics DHF/DSS has yet been

\footnotetext{
Financial support: CNPq, Capes, PDTSP

${ }^{+}$Corresponding author: barth@ioc.fiocruz.br

Received 2 July 2006

Accepted 20 September 2006
}

reported (Huang et al. 2000). Until now the great majority of mice models of DENV infection deal with suckling or young mice infected by an intracerebral route of inoculation (Nath et al. 1983, Raut et al. 1996) and with mouse-neuroadapted DENV (Desprès et al. 1998, Atrasheuskaya et al. 2003). Response of the animals (clinical symptoms and/or degree of injury) varied according to the mice strain, however the full DHF/DSS manifestations did not seem to occur in standard laboratory mice.

$\mathrm{BALB} / \mathrm{c}$ mice when infected with different strains of DENV-2 demonstrated variable results (Raut et al. 1996, Sierra et al. 1999, Huang et al. 2000). In our previous studies (Barreto et al. 2002, 2004, Paes et al. 2002), BALB/c mice infected by the intraperitoneal route with non-neuroadapted DENV-2, showed cytophatic effects in several organs like lung, liver, cerebellum, and kidney. The virus was ultrastructurally identified using electron microscopy and demonstrated by immunofluorescence techniques in C6/36 mosquito cell cultures, inoculated with the supernate of liver tissue macerate from mice after $48 \mathrm{~h}$ of infection.

$\mathrm{BALB} / \mathrm{c}$ mice infected by the intraperitoneal route with a DENV-2 strain adapted to the brain of suckling mice, demonstrated anemia, thrombocitopenia, preterminal paralysis, and shock (Atrasheuskaya et al. 2003). The analysis of the liver tissue showed extensive cell cytopathic effects as vacuolization and intracellular edema; the architecture of the hepatic lobules was partially destroyed; sinusoids were partially collapsed; only a minimal and diffusely distributed mononuclear inflammatory infiltrate was visible; blood vessels were dilated; 
some of the larger vessels were filled with fibrin and red blood cells; predominantly within the vena centralis, the endothelial lining was partially lost. Lung tissue showed some inflammatory cells and nuclear debris inside alveolar spaces. Passive congestion of the alveolar wall vessels was observed. In studies carried out by Hotta et al. (1981a) with immunocompromised mice, the replication of DENV was verified in pulmonar tissue by titulation of cell cultures inoculated with a tissue macerate.

In humans, DENV has been frequently isolated from the liver, and the antigens have been detected in Kupffer cells and hepatocytes (Rosen et al. 1989, 1999, Bhamarapravati 1997, Couverland et al. 1999). Liver function tests showed high levels of serum aspartate transaminase (AST) and serum alanine transaminase (ALT) activity, indicating hepatic injury (Kuo et al. 1992, Nguyen et al. 1997, Mohan et al. 2000). Histologically the most common features in the liver were small foci of necrosis and microvesicular steatosis (Bhamarapravati et al. 1967, Burke 1968, Fresh et al. 1969). The foci of hepatocyte necrosis may coalesce, and acidophilic bodies with pycnotic nuclei corresponding to Councilman bodies may be formed (Burke 1968, Bhamarapravati et al. 1967, Bhamarapravati 1997, Couverland et al. 1999, Huerre et al. 2001).

The DENV antigen has been localized in the cytoplasm of alveolar macrophages in human pulmonar tissue necropsies of DEN fatal cases (Miagostovich et al. 1997). Histophatological analyses of lung tissue showed interstitial pneumonia (Burke et al. 1988).

It is the intention of the present study to show the progress of viremia and to characterize the cytopathic effect in tissues of BALB/c mice infected by the intraperitoneal route with a non-neuroadapted DENV-2, in special the liver and the lung.

\section{MATERIALS AND METHODS}

Virus - The virus used in our experiments was isolated from a patient serum during an epidemic of DENV-2 in the state of Rio de Janeiro in 1995 and propagated in the Aedes albopictus mosquito cell line (C6/36) at the Flavivirus Laboratory, Departament of Virology, Instituto Oswaldo Cruz-Fiocruz, Rio de Janeiro, Brazil. The isolate was tested by the indirect immunofluorescence technique using a type specific DENV-2 monoclonal (3H5) antibody. The virus had not undergone a previous passage in mouse brain. The titer of the virus $\left(10^{6.3}\right.$ $\left.\operatorname{TCID}_{50} / 0.1 \mathrm{ml}\right)$ was calculated by the method of Reed and Muench (1938). The mice were inoculated with doses of $10,000 \mathrm{TCID}_{50} / 0.2 \mathrm{ml}$.

Animals - Adult male BALB/c mice, aged 2 months and weighing $25 \mathrm{~g}$, were obtained from the mouse colony maintained in the Department of Virology of the Instituto Oswaldo Cruz-Fiocruz. Mice were intraperitoneally inoculated with DENV-2. Non-infected mice and mice inoculated with L-15 medium were used as controls and sacrificed at the same time. Ethic permission was given by the Comission of Ethics of the Instituto Oswaldo Cruz - CEUA P0098-01.
Isolation of DENV-2 in the C6/36 cell line inoculated with the supernate of tissue macerates from $B A L B / c$ mice after 48 h of infection - Tissue (liver, lung, kidney, and cerebellum) fragments were washed in phosphate saline buffer (PBS, pH 7.2) and macerated in Leibovitz medium (L-15), supplemented with antibiotics. The suspensions were incubated for $1 \mathrm{~h}$ for antibiotic action, centrifuged at $1400 \mathrm{~g}$ for $5 \mathrm{~min}$ in a refrigerated centrifuge and the supernatants were collected. The cell monolayers were inoculated with 100 $\mu \mathrm{l}$ of supernatants and incubated for $1 \mathrm{~h}$ at $28^{\circ} \mathrm{C}$ for virus adsorption. Subsequentlly, monolayers were grown in L-15 medium supplemented with $1 \%$ non-essencial aminoacids, $10 \%$ tryptose phosphate broth, and $10 \%$ fetal bovine serum. The tubes were kept at $28^{\circ} \mathrm{C}$ and observed daily for viral cytopathic effects for 15 days. C6/ 36 normal monolayers were used as a negative control, while the positive control consisted of monolayers inoculated with DENV-2 at the same concentration as used to infect mice. Both monolayer controls were kept in culture for the same period as done for test monolayers.

Isolation of DENV-2 in the C6/36 cell line inoculated with serum from infected BALB/c mice Samples of blood from animals collected at 1 st up to 17 th day post-infection (p.i.) were centrifuged at 400 rpm for $5 \mathrm{~min}$ and the serum collected. The C6/36 cells monolayers were inoculated with $100 \mu \mathrm{l}$ of serum and incubated for $1 \mathrm{~h}$ at $28^{\circ} \mathrm{C}$ for virus adsorption. Subsequentlly, monolayers were grown in L-15 medium supplemented with $1 \%$ non-essencial aminoacids, $10 \%$ tryptose phosphate broth, and $10 \%$ fetal bovine serum. The tubes were kept at $28^{\circ} \mathrm{C}$ and observed daily for viral cytopathic effects for 15 days. C6/36 normal mono-layers were used as a negative control, while the positive control consisted of monolayers inoculated with DENV-2 $\left(100 \mathrm{TCID}_{50} / 0.1 \mathrm{ml}\right)$. Both monolayer controls were kept in culture for the same period as done for test monolayers.

Fotonic microscopy - The animals were peritoneally anaesthetized with $4 \%$ chloral hydrate $(0.4 \mathrm{ml} / 25 \mathrm{~g}$ of animal) and liver and lung tissues fragments were collected from infected (48 and $72 \mathrm{~h}, 13,14,17$, and 49 days p.i.) and non-infected mice. Samples were fixed in Millonig's fixative, dehydrated in ethanol and paraffinembedded. Sections ( $5 \mu \mathrm{m}$ thick) were stained with haematoxilyn and eosin.

\section{Transmission electron microscopy}

Tissues - The infected animals (48 and $72 \mathrm{~h}, 14$, and 49 days p.i.) were peritoneally anaesthetized with $4 \%$ chloral hydrate $(0.4 \mathrm{ml} / 25 \mathrm{~g}$ of animal $)$ and fixed by perfusion with $4 \%$ paraformaldeyde in sodium phosphate buffer (0.2M, pH 7.2) by $30 \mathrm{~min}$. In sequence the hepatic and pulmonar tissues were carefully collected, the fragments post-fixed by immersion in $2 \%$ glutaraldehyde in cacodylate buffer $(0.2 \mathrm{M}, \mathrm{pH} 7.2)$, dehydrated in acetone, post-fixed in $1 \%$ buffered osmium tetroxide, embedded in epoxi resin and polymerized at $60^{\circ} \mathrm{C}$ during 3 days. Semi-thin $0.5 \mu \mathrm{m}$ thick sections were obtained us- 
ing a diamond knife (Diatome) adapted to a Reichert-Jung Ultracut E microtome. The sections were stained with methylene blue and azure II solution (Humprey \& Pittman 1974) and observed using a Zeiss Axiophot light microscope. Ultra-thin 50-70 $\mathrm{nm}$ thick sections were obtained also. The sections were picked up onto copper grids and stained with uranyl acetate and lead citrate (Reynolds 1993) and observed in a Zeiss EM-900 transmission electron microscope.

Cells - C6/36 monolayers were fixed in $1 \%$ glutaraldehyde in cacodylate buffer $(0.2 \mathrm{M}, \mathrm{pH} 7.2)$, dehydrated in acetone, post-fixed with $1 \%$ buffered osmium tetroxide, embedded in epoxy resin and polymerized at $60^{\circ} \mathrm{C}$ during three days. Ultra-thin sections of 50-70 nm thickness were obtained and processed as described above.

Detection of DENV antigen in hepatic tissue by the immunoperoxidase technique - Paraffin-embedded sections of the hepatic tissue were deparaffinized in xylol and decreasing concentration of ethanol $(100,90$, and $70 \%$ ) followed by a final wash in PBS. Samples of liver from the 2 nd and 13 th day p.i. were incubated over night at $4^{\circ} \mathrm{C}$ with an anti-DENV-2 serum raised in monkey (gently provided by Dr R Galler, Laboratory of Molecular Biology of Flavivirus, Department of Biochemistry and Molecular Biology, Instituto Oswaldo CruzFiocruz) and washing with Tris-Cl buffer $(0.05 \mathrm{M}, \mathrm{pH}$ 7.6). Thereafter the samples were incubated with a rabbit anti-human IgG-horseradish peroxidase conjugate (Sigma) for $30 \mathrm{~min}$ at $3^{\circ} \mathrm{C}$. The slides were revelated with DAB (Sigma) and were counterstained with Mayer's hematoxylin. The sample controls were stained with a secondary antibody only.

Biochemical analysis of hepatic enzymes in sera Blood samples of five infected mice were collected by cardiac puncture at the $2 \mathrm{nd}, 3 \mathrm{rd}, 7 \mathrm{th}$, until the 14 th day p.i. The samples were centrifuged at $400 \mathrm{rpm}$ for $5 \mathrm{~min}$, the sera collected and the levels of alanine aminotransferase (ALT) and aspartate aminotransferase (AST) were obtained by UV optimized (IFCC) methodology (Karmen 1955), using commercial kits (Clm, Brazil).
Morphometric analysis - The surface density of hepatocytes, sinusoidal capillaries, and cell numerical density of sinusoidal cells were obtained from histological sections stained with haematoxilyn and eosin, from animals at the 2 nd, 13 th, and 17 th day p.i. A hundred and thirty images of the liver parenchyma of the non-infected and again of the infected animals, avoiding portal spaces, were obtained in a $40 \times$ objective camera. From each image, 20 hepatocytes and 10 sinusoidal spaces were measured using a public software Scion (ScionCorp, US), and all sinusoidal cells on each image were quantified.

All images were obtained with a NIKON Eclipse 104 light microscope and digitallized using a NIKON Coolpix 990 camera. Data were submitted to statistical analysis using t-test or Mann Whitney rank sum test considering $\mathrm{p}<0.05$.

\section{RESULTS}

Clinical signs - The infected BALB/c mice did not show neither signs of DENV infection nor increased mortality.

Morphology and morphometry of hepatic tissue Cytopathic effects in liver tissue of BALB/c mice infected 48 and $72 \mathrm{~h}, 13,14,17$, and 49 days with nonneuroadapted DENV-2 by the intraperitoneal route were analyzed. The histopathological, morphometric, and ultrastructural analyses of normal mice tissue did not show alterations during this time (Figs 1, 11). Observations of infected mice tissue revealed focal alterations in the initial stage (48 and $72 \mathrm{~h} \mathrm{p.i.)}$ and in the later stage of infection $(13,14,17$, and 49 days p.i.) (Table I).

Morphometrical studies showed that in the initial stage of infection the lumina of the sinusoidal capillars were significantly diminished (Fig. 1) compared with normal liver; focal swollen hepatocytes, without significantly modified average diameter, were observed. Histopathological and ultrastructural analyses revealed congested portal and centrolobular veins, inflammatory cells (Figs 12,14) and platelets inside sinusoidal capillars (Fig. 14), hepatocytes with rarefied cytoplasm (Fig. 12), altered microvilli and steatosis (Fig. 13). Vacuolization of

TABLE I

Dengue viruses serotype 2 infection in hepatic and pulmonar tissues of BALB/c mice

\begin{tabular}{|c|c|c|c|c|c|c|c|}
\hline Liver & 48 h p.i. & 72 h p.i. & $7 \mathrm{~d}$ p.i. & $13 \mathrm{~d}$ p.i. & 14 d p.i. & 17 d p.i. & $49 \mathrm{~d}$ p.i. \\
\hline Compression of sinusoidal capillars & $+1+$ & $\square$ & $\square$ & - & $\square$ & - & $\square$ \\
\hline Inflammatory infiltrate & $+1+$ & $+1+$ & $\square$ & + & $\square$ & + & + \\
\hline Presence of platelets in capillars & $+1+$ & $+1+$ & $\square$ & + & $\square$ & + & - \\
\hline Esteatosis & + & + & $\square$ & - & $\square$ & - & - \\
\hline Vacuolization and tumefaction of hepatocytes & $+1+$ & $+1+$ & $\square$ & + & $\square$ & + & + \\
\hline Vacuolization of endothelial cells & + & +++ & $\square$ & + & $\square$ & + & - \\
\hline \multicolumn{8}{|l|}{ Lung } \\
\hline Inflammatory infiltrate & +++ & +++ & + & $\square$ & + & $\square$ & + \\
\hline Presence of platelets in capillars & +++ & +++ & + & $\square$ & + & $\square$ & + \\
\hline Swelling of alveolar septa & +++ & +++ & + & $\square$ & + & $\square$ & - \\
\hline Focus of haemorrage & +++ & +++ & + & $\square$ & + & $\square$ & - \\
\hline
\end{tabular}

Occurrence of lesions in tissues: $+++=$ high, $++=$ middle, $+=$ low intensity; $-=$ not observed; $\square=$ not analyzed; $h=$ hour; $d=$ days; $p . i$. $=$ post-infection 

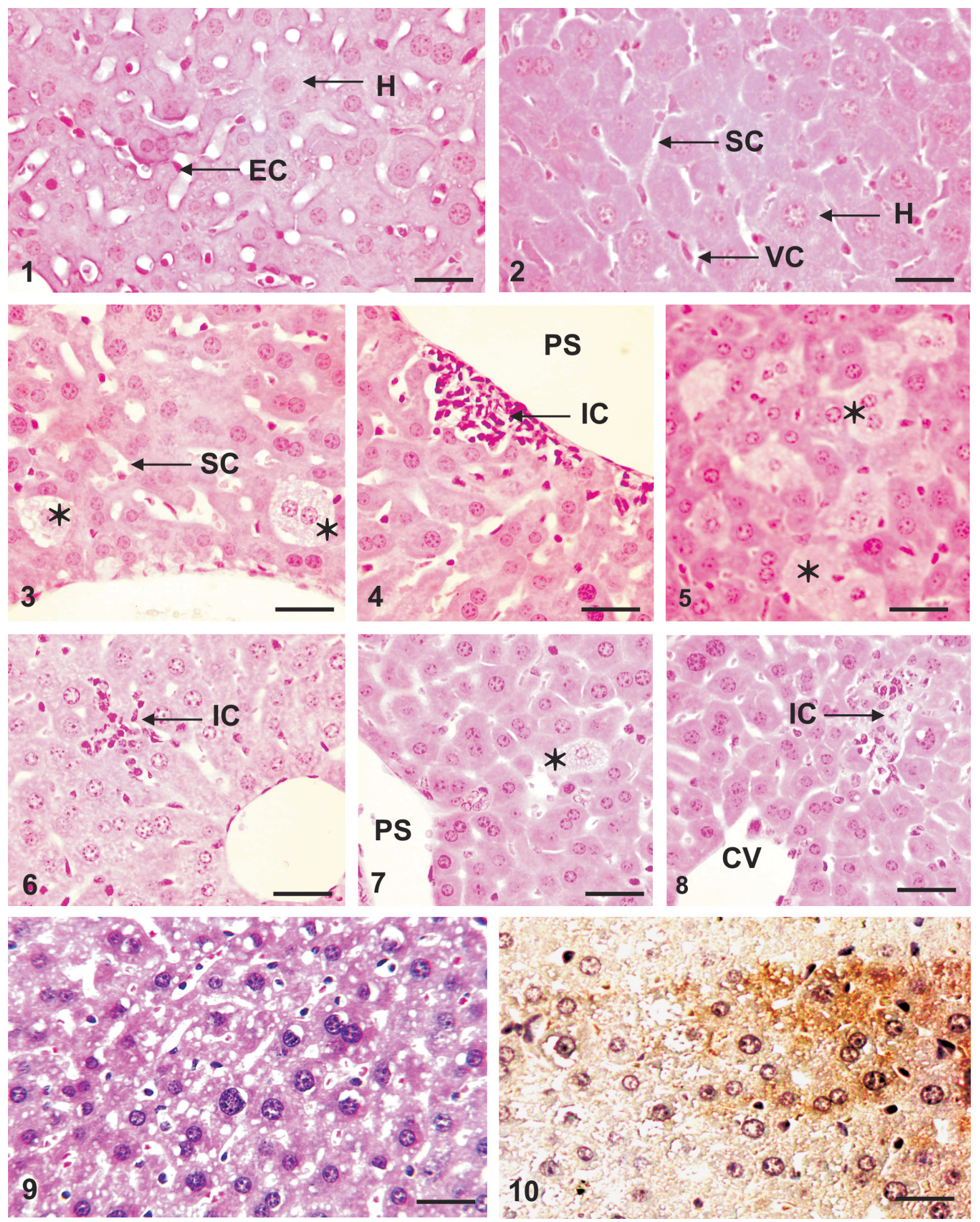

Histopathological aspects of liver tissue of BALB/c mice infected with dengue virus serotype 2, hematoxilyn-eosin staining. Fig. 1: section of normal liver of BALB/c mice showing sinusoidal capillars, normal hepatocytes and endothelial cells. Fig. 2 : hepatic tissue $48 \mathrm{~h} \mathrm{p.i.}$ showing sinusoidal capillars significantly diminished in relation to normal liver, hepatocytes, and vascular congestion. Figs 3 and 4: hepatic tissue at the 13 rd day p.i. presenting dilatation of sinusoidal capillars, tumefaction of isolated hepatocytes, and infiltrate of inflammatory cells around the portal space. Figs 5, 6: hepatic tissue at the 13rd day p.i., presenting tumefaction and vacuolization of isolated hepatocytes, and interstitial infiltrate of inflammatory cells. Figs 7, 8: hepatic tissue at the 17th day p.i., presenting tumefaction of isolated hepatocytes and interstitial infiltrate of inflammatory cells. Fig. 9: hepatic tissue presenting steatosis. Fig. 10: detection of DENV-2 antigen in hepatic tissue (brownish area) using the peroxidase technique. CV: central lobular vein, H: hepatocytes, EC: endothelial cell, IC: infiltrate of inflammatory cells, PS: portal space, SC: sinusoidal capillars, VC: vascular congestion, *: tumefaction of isolated hepatocyte. Bar $=50 \mu \mathrm{m}$ in Figs 1, 3$8 ; 40 \mu \mathrm{m}$ in Figs 2, 9 and 10. 
endothelial cells and hepatocytes was observed (Figs 9, 15).

Dilated sinusoidal capillars were observed in a later stage of infection. Histophatological and ultrastructural studies showed the presence of lipidic inclusions inside the cytoplasm, vacuolization, and tumefaction of isolated groups of hepatocytes (Figs 3, 5, 7), inflammatory cells in the interstitium (Fig. 8), the portal space (Fig. 4), and sinusoidal capillars (Fig. 6), vacuolization of endothelial cells, and alteration of Disse's space (Fig. 15).

Morphology of lung tissue - The alterations observed in lung tissue of mice infected by the intraperitoneal route were mild and focal when compared with mice controls (Fig. 16) (Table I). Inflammatory cells in the peribronchiolar space (bronchiolitis) together with platelets, and the swelling of interalveolar septa (Fig. 17) were observed from $72 \mathrm{~h}$ to 7 days p.i. These cells were still evident later, at 14 and 49 days p.i., but decreases progressively, with platelets persisting inside blood vessels (Fig. 19). Polymorphonuclear cells were recruited at a later stage, up to 14 days p.i., and hyperplasia of the bronchiolar epithelium (Fig. 18) was observed up to $72 \mathrm{~h}$ p.i. Foci of subepithelial oedema were depicted at 7 days p.i., but rare pneumocytes showed evidence of injury at this stage. They exhibited a dense cytoplasm with swollen mitochondria, whereas in the alveolar septa interstitial fibroblasts containing lipid droplets became evident. The endothelial cells maintained their structure without signs of reversible injury or necrosis as previously described (Barreto et al. 2002).

Isolation of DENV-2 in the C6/36 cell line inoculated with the supernatant of macerated tissues (liver, lung, kidney, and cerebellum) from BALB/c mice 48 h p.i. - The syncytial cytophatic effect started to be visible around the 13rd day p.i. in monolayers of the C6/ 36 cells of positive control and in the cultures inoculated with the supernatant of tissues.

In cell cultures of the positive control (Fig. 21) and in monolayer cultures inoculated with the supernatant of the tissues, the DENV-2 antigens were observed by the indirect immunofluorescence technique in liver (Fig. 22), lung, cerebellum and kidney.

Ultrastructural observations of cell cultures of the positive control (Fig. 24) and in monolayer cultures inoculated with the supernatant of the liver (Fig. 25), lung, cerebellum, and kidney showed virus particles inside cysterns of the rough endoplasmic reticulum. In the same monolayers, inoculated with the supernatant of cerebellum, virus particles presented abnormal features, frequently lacking nucleocapsids (data not shown).

At the 15th day p.i. monolayer cells of the negative control showed no morphological alterations, exhibited neither DENV-2 antigen (Fig. 20) nor virus particles (Fig. 23).

Isolation of DENV-2 in the C6/36 cell line inoculated with serum from infected BALB/c mice - Ultrastructural studies of $C 6 / 36$ cells inoculated with serum of BALB/c mice from the 2nd until the 11st day of infection (Table II) showed DENV-2 particles inside cysterns of the rough endoplasmic reticulum. Cell monolayer of the negative control (inoculated with normal serum) and inoculated with serum of 1st, 12nd, 13rd, 14th, 15th, 16th, and 17th day of infection showed no presence of viruses particles (Table II), as previously described (Paes et al. 2005).

Biochemical analysis of serum hepatic enzymes Biochemical analysis of serum showed, in general, at the 7th and 14th day p.i., levels of ALT and AST increased in most of the tested serum samples as compared to control. Apparently, both transaminases presented a peak level at the 7th day p.i. The statistical analysis of the data, however, showed no significance with $\mathrm{P}=0.051$ at the 7 th day p.i. The lack of significance was probably due to a considerable inter-individual variation, as previously described (Paes et al. 2005).

Detection of viral antigen in hepatic tissue by immunoperoxidase technique - At the 2 nd day p.i., DENV antigens were detected in focal hepatocytes (Fig. 10) and in the capillar endothelium of the central lobular vein and in hepatocytes around the portal space. They were observed at the 13rd day p.i. in groups of hepatocytes exhibiting injury. The negative control did not present any DENV-2, as previously described (Paes et al. 2005).

\section{DISCUSSION}

Dengue virus infections are one of the most important health problems in the world. There are no vaccines or prevention of DF/DHF or DSS, nor an animal model for human disease study, and higher primates do not show signs after infection (Scherer et al. 1978, Bhamarapravati 1997). The majority of models use suckling or young mice inoculated with a neuroadapted mouse DENV strain (Nath et al. 1983, Raut et al. 1996). Susceptibility of $\mathrm{BALB} / \mathrm{c}$ mice infected by the intraperitoneal route with a neuroadapted mouse DENV strain has been demonstrated (Atrasheuskaya et al. 2003). The injuries observed in our experimental mice model when mice were infected

TABLE II

Presence of virus particles in the C6/36 cell line inoculated with serum from BALB/c mice infected in different times, and observed using transmission electron microscopy

\begin{tabular}{|c|c|c|c|c|c|c|c|c|c|c|c|c|c|c|c|c|c|}
\hline \multirow[b]{2}{*}{ NS } & \multicolumn{17}{|c|}{ Days post-infection } \\
\hline & $1 \mathrm{st}$ & 2nd & $3 \mathrm{rd}$ & 4 th & 5 th & 6 th & 7 th & 8 th & 9th & 10th & 11th & 12th & 13th & 14 th & 15 th & 16th & 17 th \\
\hline- & - & + & + & + & + & + & + & + & + & + & + & - & - & - & - & - & - \\
\hline
\end{tabular}

NS: serum of normal BALB/c mice (negative control); += presence of DENV particles; $-=$ absence of DENV particles 

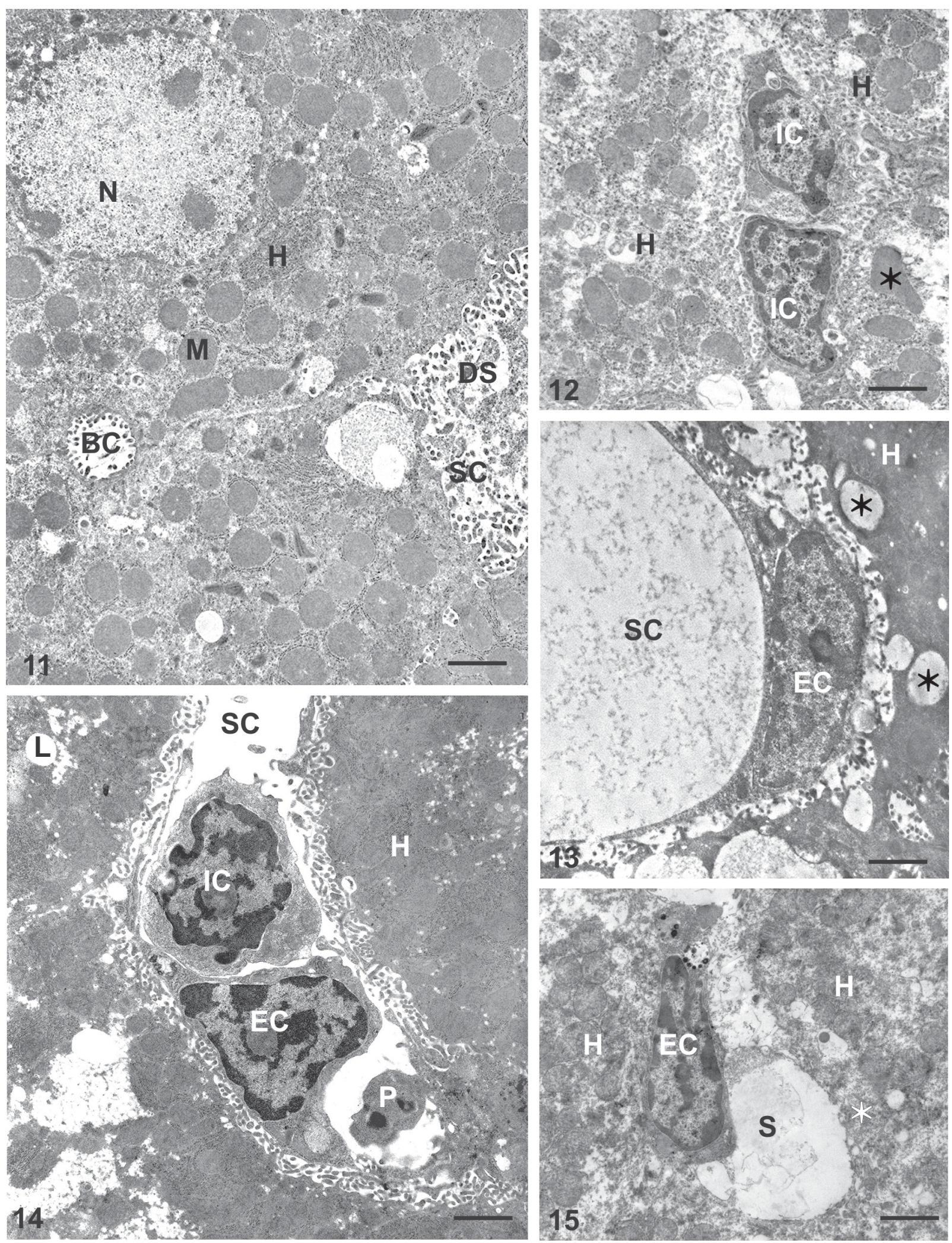

Ultrastructural analysis of of BALB/c mice liver tissue infected with dengue viruses serotype 2, uranyl acetate and lead citrate staining. Fig. 11: normal liver. Fig. 12: hepatic tissue $48 \mathrm{~h}$ p.i. showing inflammatory cells inside a sinusoidal capillar, hepatocytes with rarefied cytoplasm, and swollen mitochondria (*). Figs 13, 14: hepatic tissue $72 \mathrm{~h}$ p.i. presenting inflammatory cells, a platelet inside a sinusoidal capillar, steatosis $\left({ }^{*}\right)$ of hepatocytes, and an endothelial cell. Fig. 15: hepatic tissue 49 days p.i. showing hepatocytes, an endothelial cell with rarefied cytoplasm, and alterated Disse's space. BC: biliar canaliculi; DS: Disse's space, EC: endothelial cell, H: hepatocyte, IC: infiltrate of inflammatory cells, L: lipids, M: mitochondria, N: nucleus, P: platelet, SC: sinusoidal capillary, V: vacuolization. Bar $=2.3 \mu \mathrm{m}$ in Figs 11, 12, 14, 15; $1.8 \mathrm{~mm}$ in Fig. 13. 

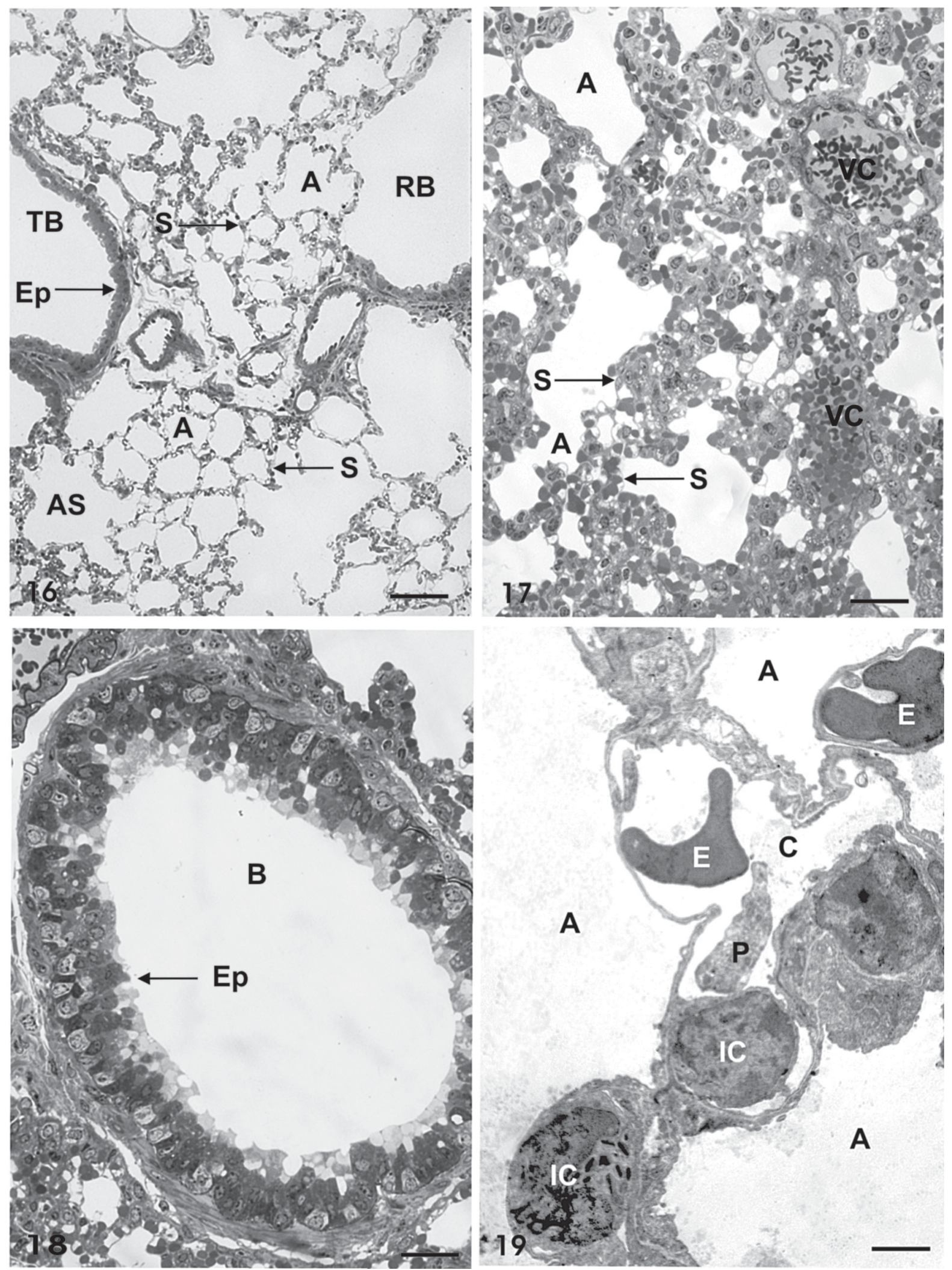

Morphological aspects of lung tissue of BALB/c mice infected with dengue viruses serotype 2. Fig. 16: semithin section of normal lung tissue, methylene blue, and azure II solution staining. Figs 17, 18: semithin sections of lung tissue $72 \mathrm{~h}$ p.i. showing vascular congestion, swelling of alveolar septa, bronchiole with hyperplastic epithelium, and alveolar space. Fig. 19: ultrathin section of lung tissue 49 days p.i., uranyl acetate and lead citrate staining, presenting capillaries with inflammatory cells, platelets, and erytrocytes inside. A: aveolar space, AS: alveolar sac, B: bronchiole, C: capillary, E: erytrocyte, Ep: epithelium, IC: inflammatory cell, RB: respiratory bronchiole, S: alveolar septum, TB: terminal bronchiole, VC: vascular congestion, P: platelet. Bar $=60 \mu \mathrm{m}$ in Fig. 16; $25 \mu \mathrm{m}$ in Figs 17, 18; $2.5 \mathrm{~mm}$ in Fig. 19. 

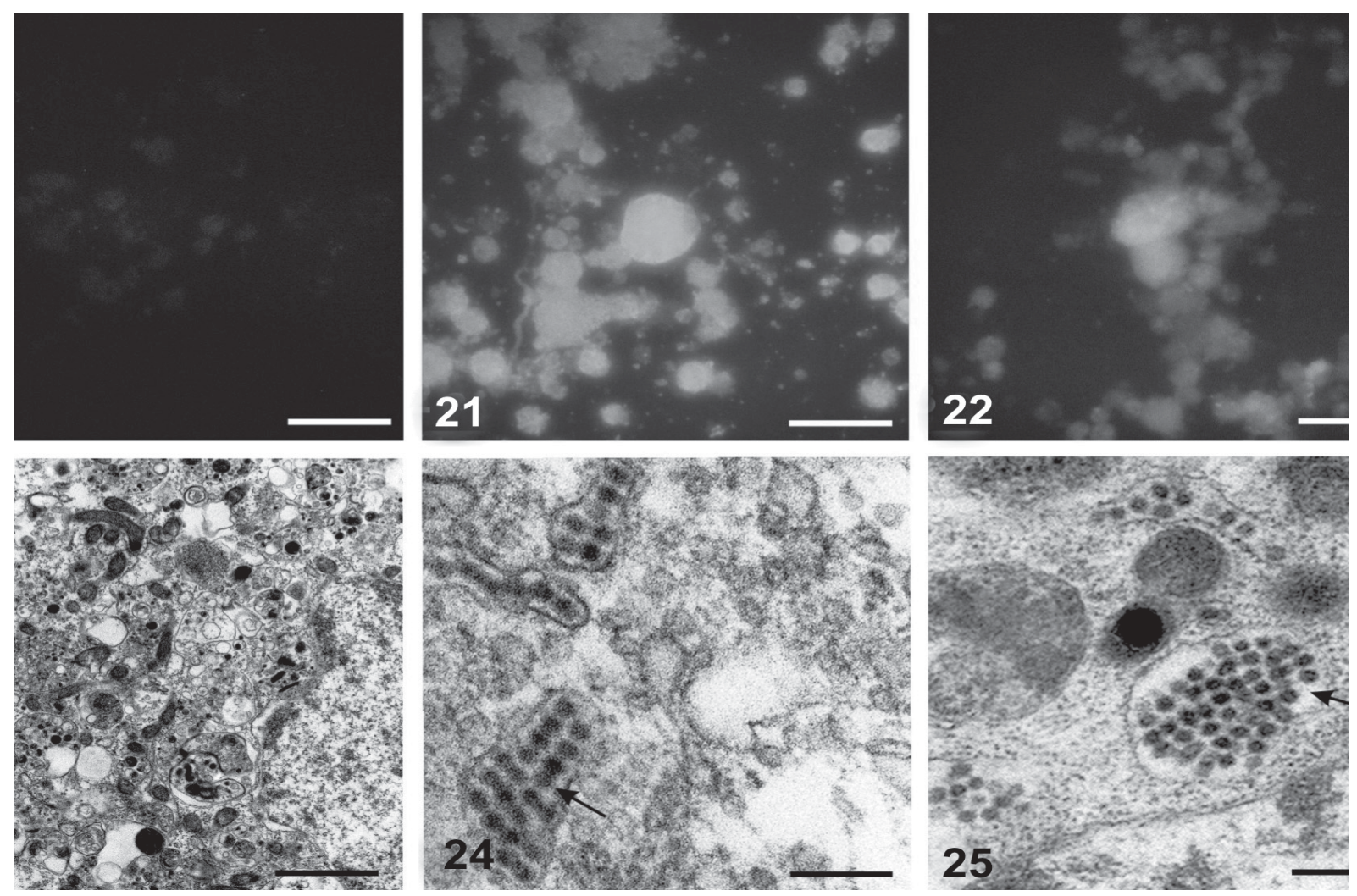

Detection of dengue viruses serotype 2 (DENV-2) antigen in C6/36 cell monolayers by the immunofluorescence technique. Fig. 20 : negative control. Fig. 21: positive control. Fig. 22: monolayer infected with the macerate of hepatic tissue supernatant. Figs 23-25: detection of DENV-2 particles in monolayers of C6/36 cells using the electron microscopy technique. Fig. 23: non-infected C6/36 cell, negative control. Fig. 24 : DENV infected C6/36 cell, positive control. Fig. 25: cell monolayer infected with the macerate of hepatic tissue supernatant. Arrows $=$ virus particles. Bar $=50$ mm in Figs 20 $-22 ; 1.25 \mu \mathrm{m}$ in Fig. 23;0.23 $\mu \mathrm{m}$ in Fig. 24; $0.35 \mu \mathrm{m}$ in Fig. 25.

by the intraperitoneal route with a non-neuroadapted DENV-2 are mild when compared with other animal models. The DENV used in the infection of these animals were neuroadapted (more virulent), or the animals were immunocompromised, or were ino-culated by the intracerebral route. We have not observed any clinical sign of disease in our experiments, and this behavior is similar to a large number of human DEN infections (Burke et al. 1988, WHO 1999).

Liver is one of the main target organ in human DEN infection, and pathologic findings including centrolobular necrosis, fatty change, Kupffer cell hyperplasia, acidophilic bodies, and monocyte infiltration of the portal tract have been reported in patients with DHF and DSS (Bhamarapravati 1989). DENV infected patients may show a severe involvement of the liver tissue resulting in death by hepatic failure (Chung et al. 1992, Lawn et al. 2003, Oliveira et al. 2005). In necropsy studies of DHF cases, hemorrhagic foci, mononuclear cell infiltrate around the portal space, with focal vacuolization in the cytoplasm of hepatocytes were observed in the liver tissue (Fresh et al. 1969, Rosen et al. 1989, 1999, Innis 1995, Bhamarapravati 1997, Couverland et al. 1999, Oliveira et al. 2005). When BALB/c mice were infected with neuroadapted DENV, serious injuries in the hepatic tissue have been observed (Atrasheuskaya et al. 2003). In the present study, the injury in hepatic tissue of $\mathrm{BALB} / \mathrm{c}$ mice infected with non-neuroadapted DENV-2 was caracterized by histological and ultrastructural observations, and in addition by biochemical and morphometrical tests. In our less virulent and focal mice model, the morphological liver alterations observed were vacuolization and tumefaction of focal hepatocytes, vacuolization of endothelial cells, inflammatory infiltrate in the interstitio, in sinusoidal capillars and in the portal space and the presence of lipidic inclusions inside the cytoplasm of hepatocytes. These injuries were similar to human DEN cases (Bhamarapravati et al. 1967, Fresh et al. 1969, Bhamarapravati, 1989, Rosen et al. 1989, 1999, Chung et al. 1992, Lawn et al. 2003, Innis 1995, Bhamarapravati 1997, Couverland et al. 1999, Oliveira et al. 2005) and some experimental mice models (An et al. 1999, Atrasheuskaya et al. 2003).

The DENV antigens could be immunolocalized in focal hepatocytes and in the capillar endothelium of the central lobular vein in BALB/c mice, $48 \mathrm{~h}$ p.i., in the present model. DENV antigen was observed also in Kupffer cells in a study with atymic nude BALB/c mice (Hotta et al. 1981). In human fatal cases of DHF, DENV has often been isolated from hepatic tissue, and the DENV 
antigen was detected in hepatocytes and in Kupffer cells (Fresh et al. 1969, Rosen et al. 1989, 1999, Innis 1995, Bhamarapravati 1997, Couverland et al. 1999, Oliveira et al. 2005). Researchers postulated that the hepatocytes and the Kupffer cells may be target cells for DENV replication (Burke 1968, Huerre et al. 2001).

The impact of DENV on liver function has been studied by biochemical tests (Kuo et al. 1992, Nguyen et al. 1997). Abnormal levels of AST and ALT were observed in patients with DEN infection. Often the DF is associated with mild to moderate elevations of such enzymes, while in patients with DHF/DSS, the AST and AST levels became remarkable higher (Kuo et al. 1992, Souza et al. 2004). In our experimental mouse model we observed peak levels of both hepatic transaminases (AST/ALT) at the 7th day p.i.; this finding is similar to human cases where the peak levels of transaminases ocurred normally at the 7th day p.i. also, and decreased during the following two weeks (Kuo et al. 1992, Souza et al. 2004).

Morphological studies of lung tissues in our experiments revealed interstitial pneumonia associated with vascular congestion, rare focal zones of parenquimal haemorrhage, increase of alveolar macrophages number, recruiting of platelets, mononuclear and polymorfonuclear cells. Histological alterations were still observed in 49 days p.i., being less severe in this time. This tissular alterations were similar in other animal models (Hotta et al. 1981, Bhamarapravati 1989, Atrasheukaya et al. 2003) and in necropsies of human pulmonar tissues of DEN fatal cases (Burke 1968, Miagostovich et al. 1997).

Virus particles and DENV antigen could be detected in monolayers of $\mathrm{C} 6 / 36$ cells inoculated with the supernate of lung macerate of infected animals in our experimental study. In immunocompromised mice, the replication of DENV was observed in lung tissue by titulation of cell cultures, inoculated with a tissue macerate (Hotta et al. 1981). DENV antigen has been localized in the cytoplasm of alveolar macrophages in DEN human cases (Miagostovich et al. 1997, Oliveira et al. 2005).

Viremia was investigated in our experimental mice model. The virus particles were observed in C6/36 cell monolayers inoculated with the animal sera from the 2 nd until the 11 st day p.i. (Paes et al. 2005) aiming to amplify the number of virus particles. Other studies using experimental mouse models (Bhamarapravati et al. 1964, Boonpucknavig et al. 1981, Nath et al. 1983, Shresta et al. 2004) were not able to caracterize the viremia, probably due to low levels of circulating DENV.

Additionally we isolated DENV particles and verified the presence of viral antigen in the $\mathrm{C} 6 / 36$ mosquito cell line inoculated with the supernate of macerates of mice kidney and cerebellum. In studies with Swiss albino mice inoculated intraperitoneally with a neuroadapted virus, DENV antigen antibody complement complexes were located in the glomeruli, but without any significant effect on the glomerular function (Boonpucknavig et al. 1981). Increase of mesangial cells was observed in DF human cases (Bhamarapravati 1997). DENV has shown the ability to invade the central ner- vous system starting from the periphery (Nathanson \& Cole 1970) and there are reports of cerebral oedema in human cases of DF, DHF and DSS (Halstead 1981). DENV antigen has been detected in the brain of human fatal cases (Miagostovitch et al. 1997, Nogueira et al. 2002).

Our results demonstrate that BALB/c mice when infected with non-neuroadapted DENV by the intraperitoneal route are capable to develop DENV infection. We showed in addition the presence of viremia in the infected mice (Paes et al. 2005). The described model of dengue infection in BALB/c mice may be used for studies in viral pathogenesis, pharmacodynamics and vaccine development (Costa et al. 2006).

\section{ACKNOWLEDGMENTS}

To Dr Jussara P do Nascimento for general support, to Dr Rita MR Nogueira and the staff of the Flavivirus Laboratory, Departament of Virology, for virus isolation and characterization, to Dr Henrique Lionel Lenzi and Dr Ester Maria Mota, Department of Pathology, to Dr Ada Maria de Barcelos Alves and Simone Morais Costa, Department of Biochemistry and Molecular Biology; to the Laboratory of Image Processing, Instituto Oswaldo Cruz-Fiocruz; to Aline Vilas Boas Vianna and Vanessa Elen de França Valle for technical assistance, and also to Mr Marcos AP Marques of the Center of Laboratory Animals Breeding-Fiocruz.

\section{REFERENCES}

An J, Kimura-Kuroda J, Hirabayashi Y, Yasui K 1999. Development of novel mouse model for dengue virus infection Virology 263: 70-77.

Atrasheuskaya A, Petzelbauer P, Fredeking TM, Ignatyev G 2003. Anti-TNF antibody treatment reduces mortality in experimental dengue virus infection. FEMS Immunol Med Microbiol 35: 33-42.

Barreto DF, Paes MV, Takiya CM, Pinhão AT, Côrtes LMC, Majerowicz S, Barth OM 2002. Mice lung experimentally infected with dengue-2 virus: ultrastructural aspects. Virus Rev Res 7: 47-55.

Barreto DF, Takiya CM, Paes MV, Farias-Filho J, Pinhão AT, Alves AMB, Costa SM, Barth OM 2004. Histopathological aspects of dengue-2 virus infected mice tissues and complementary virus isolation. J Submicrosc Cytol Pathol 36: 121-130.

Bhamarapravati N 1989. Hemostatic defects in dengue hemorrhagic fever. Rev Infect Dis 11 (Suppl. 4): S826-829.

Bhamarapravati N 1993. Pathology of dengue haemorrhagic fever. In P Thongcharoen, Monograph on Dengue/Dengue Haemorrhagic Fever, WHO Regional Office for South-East Asia, New Delhi, p. 72-79.

Bhamarapravati N 1997. Pathology of dengue infections. In DJ Gubler, G Kuno (eds), Dengue and Dengue Hemorrhagic Fever, Cab International, Wallingford, p. 115-132.

Bhamarapravati N, Halstead SB 1964. Studies on dengue virus infection I. Immunofluorescence localization of virus in mouse tissue. Arch Pathol 77: 538-543.

Bhamarapravati N, Yoksan S 1989. Study of bivalent dengue vaccine in volunteers. Lancet, May 13, 1 (8646): 1077.

Bhamarapravati N, Tuchinda P, Boonyapaknavik V 1967. Pa- 
thology of Thailand haemorrhagic fever: a study of $100 \mathrm{au}-$ topsy cases. Ann Trop Med Parasit 61: 500-510.

Boonpucknavig S, Vuttiviroj O, Boonpucknavig V 1981. Infection of young adult mice with dengue virus type 2 . Trans $R$ Soc Trop Med Hyg 75: 647-653.

Burke T 1968. Dengue haemorrhagic fever: a pathological study. Am J Trop Med Hyg 62: 682-692.

Burke DS, Nisalak A, Johnson DE, Scott RM 1988. A prospective study of dengue infections in Bangkok. Am J Trop Med Hyg 38: 172-180.

Chaturvedi UC, Dhawan R, Khanna M, Mathur A 1991. Breakdown of the blood-brain barrier during dengue virus infection of mice. J Gen Virol 72: 859-866.

Chung HK, Dar IT, Chi SCC, Chi KL, Shue SC, Yun FL 1992. Liver biochemical test and dengue fever. Am J Trop Med Hyg 47: 265-270.

Cole GA, Wisseman Jr CL 1969. Pathogenesis of type 1 dengue virus infection in suckling, weanling and adult mice. I. The relation of virus replication to interferon and antibody formation. Am J Epidemiol 89: 669-680.

Cole GA, Wisseman Jr CL 1973. Pathogenesis of type 1 dengue virus infection in suckling, weaned, and adult mice. II. Immunofluorescent and histologic studies. J Comp Path 83: 243-252.

Costa SM, Paes MV, Barreto DF, Pinhão AT, Barth OM, Queiroz JLS, Armôa GRG, Freire MS, Alves AMB 2006. Protection against dengue type 2 virus induced in mice immunized with a DNA plasmid encoding the non-structural 1 (NS1) gene fused to the tissue plasminogen activator signal sequence. Vaccine 24: 195-205.

Couverland A, Marianneau P, Bedel C, Drouet MT, Vachon F, Henin D, Deubel V 1999. Report of a fatal case of dengue infection with hepatitis. Demonstration of dengue antigens in hepatocytes and liver apoptosis. Hum Pathol 30: 11061110.

Desprès P, Frenkiel M-P, Ceccaldi P-E, Dos Santos CD, Deubel V 1998. Apoptosis in the mouse central nervous system in response to infetion with mouse-neurovirulent dengue viruses. J Virol 72: 823-829.

Eckels KH 1993. Dengue virus infection, vaccines and immunization strategies. In E Kurstak, Control of Virus Diseases, Dekker, New York, p. 343-349.

Fresh JW, Reyes V, Clarke EJ, Uylangco CV 1969. Philippine hemorrhagic fever: a clinical, laboratory, and necropsy study. $J$ Lab Clin Med 73: 451-458.

Halstead SB 1981. Viral hemorrhagic fevers. J Infect Dis 143: 127-129.

Hotta H, Murakami I, Miyasaki K, Takeda Y, Shirane H, Hotta S 1981a. Inoculation of dengue virus into nude mice. J Gen Virol 52: 71-76.

Hotta H, Murakami I, Miyasaki K, Takeda Y, Shirane H, Hotta S 1981b. Localization of dengue virus in nude mice. Microbiol Immunol 25: 89-93.

Huang KJ, Li SY L, Chen SC, Liu HS, Lin YS, Yeh TM, Liu CC, Lei HY 2000. Manifestation of thrombocytopenia in dengue-2 virus-infected mice. J Gen Virol 81: 2177-2182.

Huerre MR, Lan NT, Marianneau P, Hue NB, Khun H, Hung
NT, Khen NT, Drouet MT, Huong VTQ, Há DQ, Buisson Y, Deubel V 2001. Liver histopathology and biological correlates in five cases of fatal dengue fever in Vietnamense children. Virchows Arch 438: 107-115.

Humprey CD, Pittman EE 1974. A simple methylene blue-azureII basic fuchsin for epoxy-embedded tissue sections. Stain Technology 49: 9.

Innis B 1995. Dengue and dengue hemorrhagic fever. In JS Porterfield, Kass Handbook of Infectious Disease; Exotic Viral Infections, Chapman Hall, London, p. 103-146.

Johnson AJ, Roehrig JT 1999. New mouse model for dengue virus vaccine testing. $J$ Virol 73: 783-786.

Karmen AL 1955. IFCC method for alanine aminotransferase. J Clin Invest 34: 131.

Kuo CH, Tai DI, Chang-Chien CS, Lan CK, Chiou SS, Liaw YF 1992. Liver biochemical tests and dengue fever. Am J Trop Med Hyg 47: 265-270.

Lawn SD, Tilley R, Lloyd G, Finlayson C, Tolley H, Newman P, Rice P, Harrison TS 2003. Dengue hemorrhagic fever with fulminant hepatic failure in an immigrant returning to Bangladesh. Clin Infect Dis 37: 1-4.

Lin Y, Liao CL, Chen LK, Yeh CT, Liu CI, Ma SH, Huang YY, Huang YL, Kao CL, King CC 1998. Study of dengue virus infection in SCID mice engrafted with human K562 cells. J Virol 72: 9729-9737.

Marchette NJ, Halstead SB, Falkler Jr. WA, Stenhouse A, Nash D 1973. Studies on the pathogenesis of dengue infections in monkeys. III. Sequential distribution of virus in primary and heterologous infections. J Infect Dis 128: 23-30.

Meiklejohn G, England B, Lennette EH 1952. Adaptation of dengue virus strains in unweaned mice. Am J Trop Med Hyg 1: 51-58.

Miagostovich MP, Ramos RG, Nicol AF, Nogueira RMR, CuzziMaya T, Oliveira AV, Marchevsky RS, Mesquita RP, Schatzmayr HG 1997. Retrospective study on dengue fatal cases. Clin Neuropathol 16: 204-208.

Mohan B, Patwari AK, Anand VK 2000. Hepatic dysfunction in childhood dengue infection. J Trop Pediatr 46: 40-43.

Nathanson N, Cole GA 1970. Immunosuppression and experimental virus infection of the nervous system. Adv Virus Res 16: 397-448.

Nath P, Tandon P, Gulati L, Chaturvedi UC 1983. Histological and ultrastructural study of spleen during dengue virus infection of mice. Indian J Med Res 78: 83-90.

Nguyen TL, Nguyen TH, Tieu NT 1997. The impact of dengue haemorrhagic fever on liver function. Res Virol 148: 273277.

Nogueira RMR, Filipis AM, Coelho JM, Sequeira PC, Schatzmayr HG, Paiva FG, Ramos AM, Miagostovich MP 2002. Dengue virus infection in central nervous system (CNS): case report from Brazil. Southeast Asian J Trop Med Publ Health 33: 68-71.

Oliveira CAB, Aguiar GR, Baldanza MS, Barth OM, Silva WAE, Paes MV 2005. Pathologic study of a fatal case of dengue3 virus infection in Rio de Janeiro, Brazil. Braz J Infect Dis 9: 341-347.

Paes MV, Barreto DF, Pinhão AT, Takiya CM, Côrtes LMC, 
Majerowicz S, Barth OM 2002. Ultrastructural aspects of mouse liver infected with dengue-2 virus. Virus Rev Res 7: 38-46.

Paes MV, Pinhão AT, Barreto DF, Alves AMB, Costa SM, Takiya CM, Farias-Filho JC, Barth OM 2005. Liver injury and viremia in mice infected with dengue-2 virus. Virology 338: 236-246.

Raut CG, Deolankar RP, Kolhapure RM, Goverdhan MK 1996. Susceptibility of laboratory-bred rodents to the experimental infection with dengue virus type 2. Acta Virol 40: 143-146.

Reed LJ, Muench H 1938. A simple method of stimating fifty percent endpoints. Am J Hyg 27: 493-497.

Reynolds 1963 . The use of lead citrate at high $\mathrm{pH}$ as an electron opaque stain in electron microscopy. J Cell Biol 17: 208212.

Rosen L, Drouet MT, Deubel V 1999. Detection of dengue virus RNA by reverse transcription-polymerase chain reaction in the liver and lymphoid organs but not in the brain in fatal human infection. Am J Trop Med Hyg 61: 720-724.

Rosen L, Khin MM, Tin U 1989. Recovery of virus from the liver of children with fatal dengue. Reflections on the pathogenesis of disease and its possible analogy with that of yellow fever. Res Virol 140: 351-360.

Scherer WF, Russell PK, Rosen L, Casals J, Dickerman RW
1978. Experimental infection of chimpanzees with dengue viruses. Am J Trop Med Hyg 27: 590-599.

Shresta S, Jennifer LK, Robert B, Harris E 2004. Early activation of natural killer and $\mathrm{B}$ cells in response to primary dengue virus infection in A/J mice. Virology 319: 262-273.

Sierra VB, Perez DAB, Vazquez VV, Rodriguez DR, Garcia MG, Guzman TMG 1999. Assessment of the cellular response induced in BALB/c mice with dengue virus 2 envelope protein. Rev Cubana de Med Trop 51: 95-98.

Singh KRP 1967. Cell cultures derived from larvae of Aedes albopictus (Skuse) and Aedes aegypti (L.). Curr Sci 36: 506508.

Souza LJ, Alves JG, Nogueira RMR, Neto CG, Bastos DA, Siqueira EWS, Filho JTDS, Cezário TA, Soares CE, Carneiro RC 2004. Aminotransferase changes and acute hepatitis in patients with dengue fever: analysis of 1,585 cases. Brazilian J Infect Dis 8: 156-163.

WHO-World Health Organization 1999. Prevention and control of dengue and dengue haemorrhagic fever. Comprehensive guidelines. New Delhi, India. WHO Regional publication, SEARO, Nr 29, p. 134.

Wu SLJ, Hayes CG, Dubois DR, Windheuser MG, Kang YH, Watts DM, Sieckmann DG 1995. Evaluation of the severe combined immunodeficient (SCID) mouse as an animal model for dengue viral infection. Am J Trop Med Hyg 52: 468-476. 